\title{
ACCOUNTING DUALISM - PARTICULARITIES AND INFORMATION SOURCE FOR INTERNAL AND EXTERNAL USERS IN ORGANIZATIONAL DEVELOPMENT
}

\author{
Alina CIUHUREANU \\ alinaciuhureanu@yahoo.com \\ "NICOLAE BÄLCESCU" LAND FORCES ACADEMY, SIBIU, ROMANIA
}

\begin{abstract}
Knowing the fact that in the market economy the most important resource is the information and, naturally, since the accounting cannot be substituted for the manager, instead it offers the information necessary for the decision-making processes. The paper highlights, on the basis of bibliographic resources, that a dual accounting representation responds best to all strategic requirements and leads to a better visualization of the entity as a whole, as well as of each structure. Also, in the paper we analyzed, through a selective research, the degree to which the provision of accounting information to various categories of interested users contributes to the development of the entity.
\end{abstract}

\section{KEYWORDS:}

Accounting dualism, external users, information, internal users, management, system

\section{Introduction}

From the perspective of accounting systems, the culture highlighted the existence of two groups, namely the Anglo Saxon and the group of countries of continental Europe. These influenced the emergence of the continental and AngloSaxon accounting systems. From the organizational perspective, the accounting systems are divided into two types: the monist or integrated system and the dualist system (Minu, 2001).

The accounting system applied in Romania knew both types of organizations. If, until 1994, the integrated system (monist) was used, the management accounting was found integrated in the general accounting system (Ghintuială, 2008), whose objective was to provide the information necessary to the state for planning, statistics and control economy (Ionescu, 2003), after 1990 the political changes and the influence of the culture of the European countries (especially France) led to the adoption, in 1994, of the dualist system.

Regarding the integrated system (monist), this implies a simple organization of the accounting, without making differences between the information circuits that target both sides of the organization (Mociar, 2013) - internal and external.

The informational needs determined the appearance of the accounting dualism, respectively the construction of two representations of the same reality: one "internal" and another "external", each of 
them having specific functions, under the conditions in which one of the most important sources of data and information for the information system and implicitly for management is the accounting, whose object is very well detailed by the Accounting Law no. 82/1991. The same law also stipulates the accounting dualism in Romania, the entities being obliged to organize and to manage both the financial accounting and the management accounting. The main characteristic of the dualist system, based on formal dualism, material and informational pluralism, is that it constitutes a means of communication with the external environment - it offers a regulated image on the financial position and performance - and internally - confidential information for management, information generated by targeting the external and internal flows of the organization.

\section{Information particulars that differentiate the modules of accounting dualism}

Given the regulations and information needs, in Table no. 1 we present a parallel between the two categories of information provided through the modules of accounting dualism.

Table no. 1

Differentiations between the information provided through the modules of accounting dualism

\begin{tabular}{|c|c|}
\hline $\begin{array}{l}\text { Specific characteristics of the information } \\
\text { provided through the financial accounting } \\
\text { module }\end{array}$ & $\begin{array}{l}\text { Specific characteristics of the information } \\
\text { provided through the management } \\
\text { accounting module }\end{array}$ \\
\hline $\begin{array}{l}\text { - the information is intended for both external } \\
\text { and internal users, resulting in their public } \\
\text { character. }\end{array}$ & $\begin{array}{l}\text { - the information is intended exclusively for } \\
\text { internal users, being confidential. }\end{array}$ \\
\hline $\begin{array}{l}\text { - the reported information aims to present } \\
\text { assets, liabilities and equity, expenses, income } \\
\text { and result and the information provided relates } \\
\text { to the financial year. }\end{array}$ & $\begin{array}{l}\text { - provide managers with information for } \\
\text { planning and control, and the information } \\
\text { provided is related to the operating cycle. }\end{array}$ \\
\hline $\begin{array}{l}\text { - is based on rules, methods and principles of } \\
\text { unitary organization, nationally and } \\
\text { internationally recognize. }\end{array}$ & $\begin{array}{l}\text { - the organization is required but the concrete } \\
\text { way of accomplishing it is based on one } \\
\text { principle: generating useful information. }\end{array}$ \\
\hline $\begin{array}{l}\text { - uses historical information and often depends } \\
\text { from fiscal regulations; it only notices the } \\
\text { realities in monetary form; the result is } \\
\text { insufficient for an efficient management of the } \\
\text { organization. }\end{array}$ & $\begin{array}{l}\text { - uses any kind of information considered useful } \\
\text { and contributing to the purpose; notify realities } \\
\text { in any form of evaluation. }\end{array}$ \\
\hline $\begin{array}{l}\text { - information is oriented to the past, based on } \\
\text { documents originating mainly from the } \\
\text { external environment. }\end{array}$ & $\begin{array}{l}\text { - is oriented towards the future, based on } \\
\text { documents originating mainly from the } \\
\text { internal environment. }\end{array}$ \\
\hline $\begin{array}{l}\text { - the information is intended mainly for the } \\
\text { analysis of financial performance and position. }\end{array}$ & $\begin{array}{l}\text { - the information is intended for feedback and } \\
\text { control of internal performance; }\end{array}$ \\
\hline $\begin{array}{l}\text { - the information is aggregated, centralized, at } \\
\text { the organizational level. }\end{array}$ & $\begin{array}{l}\text { - can be obtained decentralized, at the } \\
\text { organizational centre level. }\end{array}$ \\
\hline - reports made at predetermined intervals. & - reports are made when required/requested. \\
\hline - reports are usually standardized. & $\begin{array}{l}\text { - reports are non-standardized, influenced by the } \\
\text { users' information needs and the nature of the } \\
\text { business. }\end{array}$ \\
\hline
\end{tabular}

(Source: own processing according to the references Sucală, 2004; Needles et. al., 2000; Feleagă \& Ionaşcu, 1998; Bragg, 2018; Paliu-Popa \& Godeanu, 2007; Balteş \& Ciuhureanu, 2009; Grosu, 1998; Horomnea \& Tabără, 2002; Oprea \& Cârstea, 2002; Zwass, 2015) 
In order for accounting dualism to prove its usefulness in management, the information must be generated in such a way as to answer a series of questions such as: whom is it addressed to, where are they obtained from, what is intended by their use, where and how are they circulating, what are the necessary documents, during which period the information must be presented?

Even if the two subsystems of accounting complement each other in an informational aspect, the delimitation between them is, first of all, a way of dividing between the information that the organization is obliged, willing or interested to make public and the information that it keeps for own needs and exclusivity.

\section{Selective research methodology}

As we have pointed out previously, accounting dualism is a necessity from the perspective of the information users, the two accounting circuits satisfying the internal or external information needs, the final goal being that of long-term development. Based on these aspects, we conducted a selective research on a sample of 301 organizations whose objective is to identify the degree to which the provision of accounting information to various categories of interested users contributes to the development of the entity. The objectives, hypotheses and variables used to carry out the research are presented in Table no. 2.

Table no. 2

Objectives, hypotheses and variables of the research

\begin{tabular}{|c|c|c|c|c|}
\hline Main objective & Main hypothesis & $\begin{array}{l}\text { Secondary } \\
\text { objective }\end{array}$ & $\begin{array}{l}\text { Secondary } \\
\text { hypothesis }\end{array}$ & Variables \\
\hline $\begin{array}{l}\mathbf{Q}_{1} \text { Analysis of } \\
\text { the degree to } \\
\text { which the } \\
\text { provision of } \\
\text { accounting } \\
\text { information } \\
\text { contributes to the } \\
\text { long-term } \\
\text { development of } \\
\text { organizations. }\end{array}$ & $\begin{array}{l}\mathbf{I P}_{\mathbf{1}} \text { Providing } \\
\text { accounting } \\
\text { information to } \\
\text { interested external } \\
\text { and internal users } \\
\text { is largely an } \\
\text { opportunity for } \\
\text { the management } \\
\text { and development } \\
\text { of the } \\
\text { organization. }\end{array}$ & $\begin{array}{l}\text { QS }_{1} \text { Identification } \\
\text { of opinions } \\
\text { regarding the } \\
\text { provision of } \\
\text { accounting } \\
\text { information to } \\
\text { users and the } \\
\text { contribution to the } \\
\text { management and } \\
\text { development of } \\
\text { the organization } \\
\text { according to the } \\
\text { activity field and } \\
\text { the category of } \\
\text { the organizations. }\end{array}$ & $\begin{array}{l}\text { IS }_{1} \text { Large } \\
\text { organizations in } \\
\text { industry are the } \\
\text { ones which are } \\
\text { most aware of the } \\
\text { opportunities that } \\
\text { can arise by } \\
\text { providing } \\
\text { accounting } \\
\text { information. }\end{array}$ & $\begin{array}{l}v 1 \text { Multiple } \\
\text { choice / Closed } \\
\text { with a single } \\
\text { answer } \\
v 2 \text { Multiple } \\
\text { choice / Closed } \\
\text { with a single } \\
\text { answer } \\
v 20 \text { Multiple } \\
\text { choice / } 5 \text { point } \\
\text { Likert Scale } \\
v 21 \text { Multiple } \\
\text { choice / } 5 \text { point } \\
\text { Likert Scale }\end{array}$ \\
\hline
\end{tabular}

4. Results and conclusions of the selective research

A first category of information users is represented by external users, their information needs being multiple. The data collected through the selective research are centralized in Table no. 3 . 
Table no. 3

Providing accounting information to interested external users is an opportunity for the management and development of the organization

\begin{tabular}{|c|l|c|c|c|}
\hline Valid & \multicolumn{1}{|c|}{ 301 } & Frequency & Percentage & Valid percentage \\
\hline & to a very small extent & 73 & 24,25 & 24,25 \\
\hline & to a small extent & 102 & 33,89 & 33,89 \\
\hline & neutral & 35 & 11,63 & 11,63 \\
\hline & to a large extent & 61 & 20,27 & 20,27 \\
\hline & to a very large extent & 30 & 9,97 & 9,97 \\
\hline & Total & 301 & 100,00 & 100,00 \\
\hline Score & 2,58 & & & \\
\hline
\end{tabular}

(Source: own processing)

To detail the conclusions, we formulated the secondary objective $\mathrm{QS}_{1}-$ Identification of the opinions regarding the provision of accounting information to the interested external and internal users and the contribution for the management and development of the organization according to the activity field and the category of organizations for which we proceeded to variable associations (v20 with $\mathrm{v} 1$, v20 with v2). The information obtained is shown in Tables no. 4 and no. 5.

Table no. 4

Opinion on providing accounting information to interested external users and contributing to the management and development of the organization by category

\begin{tabular}{|l|l|l|l|l|l|}
\hline \multirow{2}{*}{ Opinion } & \multicolumn{4}{|c|}{ Category* } & Total \\
\cline { 2 - 6 } & \multicolumn{1}{|c|}{ micro } & \multicolumn{1}{|c|}{ small } & middle-sized & large & \% \\
\hline To a very small extent \% & 33,11 & 23,81 & 7,69 & 0,00 & 24,25 \\
\hline To a small extent \% & 52,70 & 23,81 & 7,69 & 0,00 & 33,89 \\
\hline Neutral \% & 7,43 & 20,24 & 9,62 & 11,76 & 11,63 \\
\hline To a large extent \% & 6,08 & 22,62 & 40,38 & 70,59 & 20,27 \\
\hline To a very large extent \% & 0,68 & 9,52 & 34,62 & 17,65 & 9,97 \\
\hline Score & 1,89 & 2,70 & 3,87 & 4,06 & 2,58 \\
\hline
\end{tabular}

* Depending on the average number of employees (Source: own processing)

Table no. 5

Opinion on providing accounting information to interested external users and contributing to the management and development of the organization by field of activity

\begin{tabular}{|l|l|l|l|l|l|}
\hline \multirow{2}{*}{ Opinion } & \multicolumn{4}{|c|}{ Category } & \multirow{2}{*}{$\begin{array}{c}\text { Total } \\
\text { \% }\end{array}$} \\
\cline { 2 - 5 } & \multicolumn{1}{|c|}{ Trade } & \multicolumn{1}{|c|}{ Industry } & Services & Agriculture & 24,25 \\
\hline To a very small extent \% & 24,59 & 9,33 & 31,61 & 20,00 & 24,259 \\
\hline To a small extent \% & 36,07 & 20,00 & 40,00 & 30,00 & 33,89 \\
\hline Neutral \% & 11,48 & 17,33 & 7,10 & 40,00 & 11,63 \\
\hline To a large extent \% & 18,03 & 34,67 & 14,84 & 10,00 & 20,27 \\
\hline To a very large extent \% & 9,84 & 18,67 & 6,45 & 0,00 & 9,97 \\
\hline Score & 2,52 & 3,33 & 2,25 & 2,40 & 2,58 \\
\hline
\end{tabular}

(Source: own processing)

Analyzing the information obtained from the processing of the data related to the operational variable as well as the associations, we first conclude that the respondents have a neutral opinion (score 2.58 , which is very close to "to a small extent") regarding the benefits obtained by providing the accounting information to 
interested external users. The analysis by category reveals that the big organizations are the ones that are aware of the opportunities that can arise by providing the accounting information to the interested external users, the score obtained being 4.06. As the size of the organization decreases, so do the opinions of the respondents, the calculated scores being reduced to 1.89 (to a small extent) for organizations in the micro category. Analyzing the information based on the weights obtained, $70.59 \%$ of the large organizations consider that it is largely appropriate to provide the accounting information to the interested external users, the weight being smaller for the medium organizations $(40.38 \%)$ and almost non-existent (6.08 \%) for microentities that do not perceive opportunities (33.11\% consider that they contribute to a very small extent and $52.70 \%$ fall into the category "to a small extent").
Regarding the analysis of the opinion on the usefulness of providing the accounting information to the external users according to the field of activity, we can notice some scores that fit the answers received from the organizations from services and agriculture in the area of "to a small extent" (scores of 2.25 , respectively 2.40 ) while trade organizations (score 2.52) and industry (3.33) fall within the neutral range. It is interesting that for the organizations in the industry field, a relatively low score was obtained compared to the results obtained by analyzing other operational variables.

But what is the situation when providing accounting information to interested internal users? The data collected for this category are shown in Table 6 and the information obtained by the associations depending on category and field of activity (v21 with v1, v21 with v2) achieved to meet the secondary objective QS1 are presented in Tables no. 7 and no. 8 .

Table no. 6

The provision of accounting information to interested internal users contributes to the development of the organization

\begin{tabular}{|l|l|c|c|c|}
\hline Valid & \multicolumn{1}{|c|}{$\mathbf{3 0 1}$} & Frequency & Percentage & Valid percentage \\
\hline & to a very small extent \% & 9 & 2,99 & 2,99 \\
\hline & to a small extent \% & 40 & 13,29 & 13,29 \\
\hline & neutral \% & 21 & 6,98 & 6,98 \\
\hline & to a large extent \% & 96 & 31,89 & 31,89 \\
\hline & to a very large extent \% & 135 & 44,85 & 44,85 \\
\hline & Total & 301 & 100,00 & 100,00 \\
\hline Score & 4,02 & & & \\
\hline
\end{tabular}

(Source: own processing)

Table no. 7

Opinion on providing accounting information to interested internal users and contributing to the management and development of the organization by category

\begin{tabular}{|c|c|c|c|c|c|}
\hline \multirow{2}{*}{ Opinion } & \multicolumn{4}{|c|}{ Category* } & \multirow{2}{*}{$\begin{array}{c}\text { Total } \\
\% \\
\end{array}$} \\
\hline & micro & small & middle-sized & large & \\
\hline To a very small extent $\%$ & 6,08 & 0,00 & 0,00 & 0,00 & 2,99 \\
\hline To a small extent $\%$ & 25,68 & 2,38 & 0,00 & 0,00 & 13,29 \\
\hline Neutral \% & 12,16 & 3,57 & 0,00 & 0,00 & 6,98 \\
\hline To a large extent $\%$ & 34,46 & 30,95 & 30,77 & 17,65 & 31,89 \\
\hline To a very large extent $\%$ & 21,62 & 63,10 & 69,23 & 82,35 & 44,85 \\
\hline Score & 3,40 & 4,55 & 4,69 & 4,82 & 4,02 \\
\hline
\end{tabular}

* Depending on the average number of employees (Source: own processing) 
Table no. 8

Opinion on providing accounting information to interested internal users and contributing to the management and development of the organization by field of activity

\begin{tabular}{|l|l|l|l|l|l|}
\hline \multirow{2}{*}{ Opinion } & \multicolumn{4}{|c|}{ Field of activity } & Total \\
\cline { 2 - 5 } & \multicolumn{1}{|c|}{ Trade } & \multicolumn{1}{|c|}{ Industry } & \multicolumn{1}{c|}{ Services } & Agriculture & \% \\
\hline To a very small extent \% & 1,64 & 0,00 & 5,16 & 0,00 & 2,99 \\
\hline To a small extent \% & 18,03 & 4,00 & 15,48 & 20,00 & 13,29 \\
\hline Neutral \% & 14,75 & 5,33 & 1,94 & 50,00 & 6,98 \\
\hline To a large extent \% & 24,59 & 28,00 & 36,77 & 30,00 & 31,89 \\
\hline To a very large extent \% & 40,98 & 62,67 & 40,65 & 0,00 & \\
\hline Score & 3,85 & 4,49 & 3,92 & 3,10 & 4,02 \\
\hline
\end{tabular}

(Source: own processing)

By processing the information aimed at interested internal users, we notice that the situation is radically changing. Processing v21 generated a score of 4.02 , which reveals that it is generally considered that the provision of accounting information to interested internal users contributes greatly to the development of the organization. The analysis by category clearly highlights the importance given to this aspect by the organizations of the big, medium and small categories, the scores being between 4.82 and 4.55 which shows that the provision of the accounting information to the interested internal users contributes to a great extent in the management of the organization and the development of the business. Moreover, the field that considers that providing accounting information to interested internal users is largely important (score 4.49) is again that of the industry. At the opposite pole is the field of agriculture with a score of 3.10 (neutral opinion), trade with 3.85 and services with a score of 3.92 .

\section{Conclusions}

The results of the research have led to the validation of the secondary hypothesis IS1 - Large organizations are those who are most aware of the opportunities that may arise by providing accounting information to interested external and internal users. The field of activity in which the highest interest is expressed is that of the industry. Based on the formulated conclusions, the advanced hypothesis (IP1 - Providing accounting information to interested external and internal users is largely an opportunity for the management and development of the organization) is partially confirmed.

Regarding the benefits of providing accounting information to interested external users, we conclude that respondents have a neutral opinion. By processing the information aimed at interested internal users, the situation has changed radically, the research demonstrating that generally it is considered that providing accounting information to interested internal users contributes greatly to the development of the organization. Analysis by category and field of activity showed that large organizations are the ones that are most aware of the opportunities that may arise by providing accounting information to interested external and internal users and the area of activity in which the highest interest is manifested is that of the industry. 


\section{REFERENCES}

Balteș, N., \& Ciuhureanu, A. T. (2009). Contabilitate. Fundamente teoretice și practice. Sibiu: Editura Universității "Lucian Blaga".

Bragg, S. (2018). The difference between financial and managerial accounting, available at: https://www.accountingtools.com/articles/what-is-the-difference-betweenfinancial-and-managerial-acco.html, accessed on 03 November 2019.

Feleagă, N., \& Ionaşcu, I. (1998). Tratat de contabilitate financiară. Vol. 1, Bucureşti: Editura Economică.

Ghintuială, A. (2008). Actualități și perspective în normalizarea contabilă internațională. International Conference on European Integration - Realities and Perspectives (EIRP) Proceedings, Vol. 3, 506.

Grosu, C. (1998). Sistemul informaţional contabil - sursă a controlului de gestiune. Gestiunea şi contabilitatea organizaţiei. nr. 6, 49.

Horomnea, E., \& Tabără, N. (2002). Locul contabilităţii în sistemul general al clasificării ştiinţelor. Finanţe publice şi contabilitate, Issue 5, 11.

Ionescu, C. (2003). Informarea financiară în contextul internaţionalizării contabilităţii. Bucureşti: Editura Economică.

Minu, M. (2001). Monismul şi dualismul contabil - opţiuni în organizarea sistemului informaţional contabil. Contabilitatea, expertiza şi auditul afacerilor, Issue 7, 17-19.

Mociar, I. (2013). Sistemul informațional contabil pentru managementul întreprinderii. Tribuna Economică.

Needles, E. B., Henry, A. R., \& Caldwell, C. J. (2000). Principiile de bază ale contabilităţii. Chişnău: Editura Arc.

Oprea, C., \& Cârstea, G. (2002). Contabilitatea de gestiune şi calculaţia costurilor. București: Editura Genicod.

Paliu-Popa, L., \& Godeanu, I. C. (2007). Resemblances and differences between financial accounting and management accounting. Annals of the University of Petroşani, Economics, Vol. 7, 283-288.

Romanian Parliament. (1991). Law no. 82/1991 - Law on Accounting, republished, as subsecquently amended and supplemented. Bucharest: Official Gazette. no. 454/18 June 2008.

Sucală, L. (2004). Contabilitatea de gestiune - între reglementare şi necesitate, în condiţiile procesului de convergenţă contabilă în România. Congresul profesiei contabile din România. Armonizare sau Convergenţă în Standardele Internaţionale de Contabilitate, Bucureşti: Editura CECCAR, 822-823.

Zwass, V. (2015). Information system. Encyclopaedia Britannica, available at: http://www.britannica.com/EBchecked/topic/287895/information-system, accessed on 25 January 2015. 